\title{
Effects of Dietary Protein Content on Milk Composition of Mixed Parity Lactating Sows in a Tropical Humid Climate
}

\author{
Silva BAN ${ }^{1,2^{\star}}$, Gourdine $\mathrm{JL}^{2}$, Corrent $\mathrm{E}^{3}$, Primot $\mathrm{Y}^{3}$, Mourot $\mathrm{J}^{4}$, Noblet $\mathrm{J}^{4}$ and Renaudeau $\mathrm{D}^{2,4}$ \\ ${ }^{1}$ Institute of Agricultural Sciences/ICA, Federal University of Minas Gerais (UFMG), 39404-547, Montes Claros, Minas Gerais, Brazil \\ ${ }^{2}$ INRA UR 143 Zootechnical Research Unit, F-97170 Petit Bourg, Guadeloupe, France \\ ${ }^{3}$ Ajinomoto Eurolysine S.A.S. 153, Rue de Courcelles, F-75817 Paris Cedex 17, France \\ ${ }^{4}$ INRA, UMR Breeding Systems, Animal and Human Nutrition INRA UMR 1079, 35590 St Gilles, France
}

\begin{abstract}
Eighteen multiparous Large White sows were used to determine the effects of dietary protein content and lactation stage on milk composition during a 28-d lactation under humid tropical climatic conditions. This study was conducted at the INRA facilities in Guadeloupe, French West Indies (latitude $16^{\circ} \mathrm{N}$, longitude $61^{\circ} \mathrm{W}$ ). The average minimum and maximum ambient temperatures and average daily relative humidity during the trial were 22.7 and $29.4^{\circ} \mathrm{C}$, and $93.7 \%$, respectively. The dietary experimental treatments were a normal protein (NP, $17.3 \%$ ) diet and a low protein (LP, 14.1\%) diet supplemented with essential amino acids. The ADFI tended to be higher for the sows fed the LP diets when compared with the NP treatment (i.e., $+9 \%, P<0.10)$. Litter BW gain and mean BW of piglets at weaning were not affected by dietary protein level $(P>0.10)$. The treatments did not influence $(P>0.10)$ sow body weight loss during lactation. The sows fed LP diets tended to show lower backfat thickness losses when compared to the sows fed NP diets ( 2.4 vs. $6.3 \mathrm{~mm}$, respectively; $P<0.10)$. Milk production and composition were not affected by dietary treatments $(P>0.10)$. Milk dry matter and ash contents linearly increased according to lactation stage (17.6 to $19.9 \%$, and 0.72 vs. $97 \%$, respectively from d 7 to $d 27 ; P<0.01)$. Lactose content increased from d 7 to $d 14(3.95$ vs. $4.91 ; P<0.01)$ and thereafter remained constant. Fat content did not change during lactation and averaged $7.5 \%$. The amino acid concentrations in milk protein were affected by the lactation stage: methionine, threonine, tryptophan, valine, and alanine concentrations decreased $(P<0.05)$ but glycine and glutamic acid contents increased $(P<0.05)$ from $\mathrm{d} 7$ to $\mathrm{d} 27$. Fatty acids milk profile was not influenced $(P>0.10)$ by lactation stage. Maternal BW loss during lactation was negatively correlated with the average daily feed intake $(r=-0.76 ; P<0.05)$ and positively correlated with backfat thickness loss $(r=0.55 ; P<0.05)$. A positive correlation between milk production and body reserves mobilisation $(r=0.82 ; P<0.05)$ was also observed. Polyunsaturated fatty acid content in milk fat was positively correlated with ADFI and negatively correlated to maternal BW loss $(r=0.62$ and $r=-0.60 ; P<0.05)$. In conclusion, reducing dietary protein content can be an alternative to attenuate the negative effects of heat stress by increasing ADFI. Milk composition changes significantly according to lactation stage and the ability of sows to produce milk will depend on their capacity to mobilize body reserve for providing milk precursors.
\end{abstract}

Keywords: Sow; Lactation; Milk; Amino acids; Fatty acids

\section{Implications}

Heat stress is a constant problem in many tropical and subtropical areas. Under heat stress, sows reduce their appetite in order to reduce their metabolic heat production due to the thermic effect of feed. This reduced feed intake has negative consequences on body reserves mobilization and milk yield and composition. The way the sow's milk composition and production is affected by heat stress implicates in the need of new nutritional strategies to attend the current lactating sow's daily needs and a better understanding of the consequences of this stress towards metabolism.

\section{Introduction}

The growth rate of nursing piglets is mainly determined by milk nutrient output by the dam. As a consequence, the quantity and the composition of milk produced by sows are key factors to reach a successful piglet production. Milk production appears to be highly variable and depends on many factors. It can be affected by sow characteristics (genotype, litter size, parity number, and lactation stage) and by environmental factors (feeding management, photoperiod, climatic parameters) [1]. Under tropical conditions, we estimated that milk yield was reduced by at least 30 to $50 \%$ in comparison with data obtained in temperate countries [2]. This result is mainly connected to the combined negative effect of high ambient temperature and relative humidity resulting in a concomitant reduction of voluntary feed consumption and milk production combined with the reduced ability of the sow to mobilize maternal body reserves. In fact, under tropical conditions, because of opened or semi-opened buildings, animals are more directly exposed to nycthemeral variation of the outside climatic conditions $[3,4]$. While there is substantial information on milk composition from sows raised under temperate climate [5], data on milk composition obtained in tropical countries are scarce and limited to the general composition (total solids, protein, fat and ash contents) $[3,6]$. The objective of our study was to evaluate the amino acid and fatty acid profile of sow's milk composition according to the lactation stage and dietary protein content under tropical humid conditions. In

*Corresponding author: Bruno Silva, Institute of Agricultural Sciences/ ICA Universidade Federal de Minas Gerais (UFMG), 39404-547, Montes Claros, Minas Gerais, Brazil, Tel: +351253510223; E-mail: BrunoSilva@ufmg.br

\section{Received April 06, 2017; Accepted June 20, 2017; Published June 22, 2017}

Citation: Silva BAN, Gourdine JL, Corrent E, Primot Y, Mourot J, et al. (2017) Effects of Dietary Protein Content on Milk Composition of Mixed Parity Lactating Sows in a Tropical Humid Climate. J Vet Sci Technol 8: 448. doi: $\pi 07491 \pi 00014648$

Copyright: (c) 2017 Silva BAN, et al. This is an open-access article distributed under the terms of the Creative Commons Attribution License, which permits unrestricted use, distribution, and reproduction in any medium, provided the original author and source are credited. 
the present paper, the relationship between sow's performance and milk composition are also analysed.

\section{Materials and Methods}

Care and use of animals were performed according to the certificate of authorization to experiment on living animals issued by the French Ministry of Agriculture to the head of the experimental facilities.

\section{Animals and experimental procedure}

The study was conducted during the year of 2007 at the INRA facilities in Guadeloupe, French West Indies (latitude $16^{\circ} \mathrm{N}$, longitude $61^{\circ} \mathrm{W}$ ) characterized as having a tropical humid climate. A total of eighteen Large White mixed parity sows from 3 successive replicates of 6 sows each were used in this study. Within each replicate, sows were distributed in a completely randomized experimental design between two dietary treatments according to parity order, BW and backfat thickness after farrowing.

The dietary experimental treatments were: a normal protein diet (NP) and a low protein diet (LP) supplemented with essential AA. The experimental diets (Table 1) were formulated using corn, wheat middlings, and soybean meal, which met or exceeded AA requirements of lactating sows (NRC, 1998). The NP and LP diets contained the same levels of standardized digestible lysine (i.e., $0.80 \mathrm{~g} / \mathrm{MJ}$ of NE). The ratio between digestible essential amino acids and digestible lysine in the experimental diets were maintained by synthetic AA complementation (DL-methionine, L-threonine, L-tryptophan, L-isoleucine, L-valine) to ensure that they were not below that of the ideal protein recommended for this animal category [3]. Diets were offered as pellets. Diets were prepared for the three successive replicates and stored in a temperaturecontrolled room $\left(24^{\circ} \mathrm{C}, 50\right.$ to $\left.60 \% \mathrm{RH}\right)$.

During the gestation period, sows were housed in open-fronted gestating pens in groups of 5 sows each and restrictively fed a conventional diet containing $13 \mathrm{MJ} \mathrm{DE} / \mathrm{kg}, 140 \mathrm{~g} \mathrm{CP} / \mathrm{kg}$, based on maize, wheat middling and soybean meal. Feed allowance during the first $30 \mathrm{~d}$ after mating was calculated to standardize body condition at farrowing, according to the model proposed by Dourmad et al. [7]. The feeding level was fixed at $2.5 \mathrm{~kg} / \mathrm{d}$ from the $30^{\text {th }}$ to the $114^{\text {th }}$ of gestation. Ten days before parturition, sows were moved to open-fronted farrowing pens $(2.1 \times 2.2 \mathrm{~m})$ on a slatted metal floor. Variations in ambient temperature, relative humidity, and photoperiod closely followed outdoor conditions. On $\mathrm{d} 1$ postpartum, sows received $1 \mathrm{~kg}$ of the standard gestation diet and the allowance increased by $1 \mathrm{~kg}$ each day until $\mathrm{d} 4$ of lactation to avoid over-consumption at the beginning of lactation and agalactia problems. The proportion of gestation diet decreased progressively over the 4-d postpartum (100, 75, 50 and $25 \%$ on $\mathrm{d} 1,2,3$ and 4, respectively), and sows were fed only the lactation diet on d 5 . From d 6 to 26 postpartum, sows were allowed to consume feed ad libitum. The day prior to weaning (i.e., d 27), sows were allowed $3 \mathrm{~kg}$ of feed (i.e., at least $1.5 \mathrm{~kg}$ lower than their usual feed intake) to standardize consumption for all sows for determination of sow BW at weaning.

After birth, piglets were handled for tooth cutting, umbilical cord treatment and ear tagged for labelling. On $\mathrm{d} 3$, they received an intramuscular injection of $200 \mathrm{mg}$ of iron dextran. When necessary, cross-fostering was conducted within the first $48 \mathrm{~h}$ after birth to standardize litter size at 11 piglets. On d 14, male piglets were castrated. After $21 \mathrm{~d}$ of lactation, piglets were offered creep feed containing $15.3 \mathrm{MJ}$ of DE $/ \mathrm{kg}, 20 \% \mathrm{CP}$, and $1.47 \%$ total lysine. Infrared lights provided supplemental heat for the piglets during the first $21 \mathrm{~d}$ of the lactation period.

\section{Measurements and chemical analysis}

Sows were weighed after farrowing and at weaning. Backfat thickness measurements were taken ultrasonically (Agroscan, E.C.M., Angoulême, France) at $65 \mathrm{~mm}$ from the midline at the point beside the shoulder and at the last rib on each flank $2 \mathrm{~d}$ before farrowing and at weaning. The total number of piglets born, born alive, stillborn, and piglet deaths during lactation were recorded for each litter. Piglets were individually weighed at birth, at d 14 and 21 of lactation and at weaning. Every morning, feed refusals were collected, and fresh feed was immediately distributed once per day between 0700 and 0900 . Feed consumption was determined as the difference between feed allowance and the refusals collected on the next morning. Every day, one sample of feed and feed refusals were collected daily for DM content measurement, and successive samples were pooled and stored at $4^{\circ} \mathrm{C}$ for further analyses.

At $\mathrm{d} 7,14,21$ and 27 piglets were separated from the sows after suckling, and 50 min later (i.e., equivalent to average suckling interval) [8], the sow was injected with 10 IU of oxytocin (Intervet, Angers, France) in an ear vein and all functional mammary glands were hand milked. Samples (approximately 150 to $200 \mathrm{~mL}$ ) were immediately stored at $-20^{\circ} \mathrm{C}$ for further analyses. At the end of the experiment, all samples were freeze dried and analyzed for moisture, ash, and $\mathrm{N}$ contents according to AOAC methods [9]. Lactose content was measured using an enzymatic method (ENZYPLUS EZS784, BioControl Systems, Inc.). The amino acids contents were determined by ion-exchange liquid chromatography (Biochrom 20, Pharmacia, Saclay, France) after a 24 h-hydrolysis in $\mathrm{HCl}(6 \mathrm{~mol} / \mathrm{L})$. For sulfur AA, the hydrolysis was performed by a performic oxidation. Tryptophan was hydrolyzed only for feed and milk in barium hydroxide solution $(1.5 \mathrm{~mol} / \mathrm{L})$ for $20 \mathrm{~h}$, separated by HPLC, and detected fluorimetrically (Waters 600E, St Quentin en Yvelines, France). The total lipid content was determined following a chloroform/methanol (2:1) extraction method according to Folch et al. [10]. Fatty acid methyl esters were prepared with $20 \%$ boron trifluoride/methanol solution according to Morrison and Smith, the fatty methyl esters were separated on a gas chromatograph equipped with a SP-2330 capillary column $(30 \mathrm{~m} \times 0.25 \mathrm{~mm}$ internal diameter $)$ with a non-bonded poly ( $80 \%$ biscyanopropyl $/ 20 \%$ cyanopropylphenyl siloxane) stationary phase (a $0.20-\mu \mathrm{m}$ film thickness) [11]. Furnace temperature was $180^{\circ} \mathrm{C}$, and injector and detector temperatures were $240^{\circ} \mathrm{C}$.

Feed (two samples per diet and per replicate) samples were analyzed for $\mathrm{DM}$, ash, fat content $(\mathrm{AOAC})$ and $\mathrm{CP}(\mathrm{N} \times 6.25$ for feed and $\mathrm{N} \times 6.38$ for milk) according to Dumas method (AOAC) and analyzed for crude fiber and for cell wall components (NDF, ADF, and ADL) according to Van Soest and Wine [9]. Feed AA contents were analyzed by Ajinomoto Eurolysine (Amiens, France) using ion-exchange chromatography, except for tryptophan, which was analyzed using HPLC and fluorimetric detection (Waters 600E, St. Quentin en Yvelines, France).

\section{Calculation and statistical analysis}

Daily maximum, minimum, mean, and variance of daily ambient temperatures and relative humidities were averaged for each replicate. Milk production was estimated from litter growth rate and litter size between $\mathrm{d} 1$ and $\mathrm{d} 21$, and milk DM using the equation from Noblet and Etienne [12]. The effects of diet composition, replicate, parity number, and their interactions on performance of sows and litters were tested the GLM procedure of SAS. The effect of lactation stage on daily feed intake was tested with a mixed linear model (Mixed procedure of SAS) for repeated measurements with diet composition, batch and parity 


\begin{tabular}{|c|c|c|}
\hline Ingredients, $\%$ & Normal protein & Low protein \\
\hline Corn & 59.5 & 67.4 \\
\hline Soybean meal & 24.4 & 10.6 \\
\hline Wheat middlings & 8.4 & 14.3 \\
\hline Soybean oil & 3.4 & 2.4 \\
\hline L-lysine HCL & 0.020 & 0.415 \\
\hline DL-methionine & & 0.109 \\
\hline L-threonine & & 0.175 \\
\hline L-tryptophan & & 0.064 \\
\hline L-isoleucine & & 0.127 \\
\hline L-valine & & 0.140 \\
\hline Monocalcium phosphate & 1.0 & 1.0 \\
\hline Calcium carbonate & 2.1 & 2.1 \\
\hline Salt & 0.1 & 0.1 \\
\hline Minerals and vitamins ${ }^{2}$ & 1.1 & 1.1 \\
\hline \multicolumn{3}{|l|}{ Analyzed composition } \\
\hline Crude protein & 17.3 & 14.1 \\
\hline Starch & 39.0 & 45.2 \\
\hline Ether extract & 4.3 & 5.6 \\
\hline NDF & 10.0 & 10.8 \\
\hline \multicolumn{3}{|l|}{ Calculated composition } \\
\hline \multicolumn{3}{|l|}{ SID amino acids, $\%^{2}$} \\
\hline Lysine & 0.80 & 0.80 \\
\hline Methionine + cystine & 0.49 & 0.48 \\
\hline Threonine & 0.54 & 0.54 \\
\hline Tryptophan & 0.18 & 0.17 \\
\hline Isoleucine & 0.63 & 0.54 \\
\hline Leucine & 1.36 & 1.07 \\
\hline Valine & 0.71 & 0.65 \\
\hline \multicolumn{3}{|l|}{ Fatty acids (FA), $\%$ total $^{3}$} \\
\hline \multicolumn{3}{|l|}{ Saturated FA } \\
\hline $\mathrm{C} 16$ & 11.1 & 11.4 \\
\hline $\mathrm{C} 18$ & 2.9 & 2.6 \\
\hline Total & 14.6 & 14.6 \\
\hline \multicolumn{3}{|l|}{ Monounsaturated FA } \\
\hline $\mathrm{C} 16: 1$ & 0.2 & 0.3 \\
\hline C18:1 & 23.4 & 23.6 \\
\hline Total & 24.5 & 24.8 \\
\hline \multicolumn{3}{|l|}{ Polyunsaturated FA } \\
\hline $\mathrm{C} 18: 2$ & 54.6 & 55.1 \\
\hline C18:3 & 5.0 & 4.2 \\
\hline Total & 60.9 & 60.6 \\
\hline \multicolumn{3}{|l|}{ Calculated nutritional values ${ }^{3}$} \\
\hline Net energy, $\mathrm{MJ} / \mathrm{kg}$ & 10.2 & 10.1 \\
\hline Digestible lysine, $\mathrm{g} / \mathrm{MJ}$ of $\mathrm{NE}$ & 0.80 & 0.80 \\
\hline
\end{tabular}

${ }^{1}$ Adjusted for $88 \%$ DM; ${ }^{2}$ Standardized ileal digestible (SID) AA contents were calculated from the analyzed AA content and estimated standardized digestibility coefficients of the raw materials from INRA Tables (Sauvant et al.); ${ }^{3}$ Fatty acids composition and NE values was estimated from the chemical composition of the diet and the equation of Noblet et al.

Table 1: Composition of lactation diets, as fed basis and analyzed chemical composition of the lactation diets ${ }^{1}$.

number as main effects. The least square means procedure (PDIFF option) was used to compare means when a significant F-value was obtained. Milk composition data were submitted to a linear mixed model including the effect of diet, batch, and lactation stage as main effects. In this later model, the sow was considered as a random effect and the repeated measurement option of the mixed procedure of SAS was used with an autoregressive covariance structure to take into account the correlations between repeated measurements on the same animal. Means comparison was performed according to the Pdiff

\begin{tabular}{|c|c|c|c|c|}
\hline & \multicolumn{2}{|c|}{ Diet } & \multirow[b]{2}{*}{ RSD $^{1}$} & \multirow[b]{2}{*}{ Statistics $^{2}$} \\
\hline & $\begin{array}{l}\text { Normal } \\
\text { protein }\end{array}$ & Low protein & & \\
\hline No. of sows & 9 & 9 & & \\
\hline Parity no. & 2.5 & 3.0 & - & \\
\hline Body Weight (BW), kg & & & & \\
\hline At farrowing & 224 & 226 & 31 & \\
\hline Loss during lactation & 29 & 21 & 9 & \\
\hline Backfat thickness, mm & & & & \\
\hline At farrowing & 19.1 & 17.2 & 4.5 & \\
\hline Loss during lactation & 6.3 & 2.4 & 3.6 & $D^{t}$ \\
\hline ADFI, g/d & 4162 & 4555 & 653 & $D^{t}$ \\
\hline Litter BW gain, g/d & 2142 & 1967 & 349 & $\mathrm{~B}^{\mathrm{t}}$ \\
\hline Milk production, $\mathrm{g} / \mathrm{d}^{3}$ & 7800 & 7170 & 1450 & $\mathrm{~B}^{*}$ \\
\hline
\end{tabular}

${ }^{1}$ Residual Standard Variation; ${ }^{2}$ From an analysis of variance including the effect of diet (D), batch (B) and parity as main effects. Statistical significance: ${ }^{t} P<0.10$; $P<0.05$; ${ }^{3}$ Milk production during lactation was calculated from litter BW gain, litter size between $\mathrm{d} 1$ and 27 using the equation from Noblet and Etienne.

Table 2: Effects of dietary protein content on performance of lactating sows over a 28-d lactation (least square means)

option of SAS procedure using Tukey test for contrasts. Residual values were computed from the preceding models (without the random sow effect) and residual Pearson correlations between lactating performance and mean milk composition parameters were calculated using the CORR Procedure of SAS/STAT.

\section{Results and Discussion}

Average minimum and maximum ambient temperatures and average daily relative humidity measured during the experimental period were 22.7 and $29.4^{\circ} \mathrm{C}$, and $93.7 \%$, respectively. After farrowing, sows were restrictively fed for $5 \mathrm{~d}$ according to the same feeding plan and the increase of ADFI was similar for both treatments until $\mathrm{d} 4$. After $\mathrm{d} 4$, ADFI tended to be higher for LP diet as compared to the NP diet during the lactation (i.e., 4.55 vs. $4.16 \mathrm{~kg} / \mathrm{d}$, respectively; $P=0.08$; Table 2).

Similarly to our findings, Renaudeau and Noblet evaluating the effect of protein reduction (14.2 vs. $17.6 \%)$ also reported a numerical increase of ADFI in heat stressed $\left(29^{\circ} \mathrm{C}\right)$ sows (fed LP diet $(+0.639$ $\mathrm{kg} / \mathrm{d})$ [13]. Lynch also observed an increased feed consumption $(+0.700$ $\mathrm{kg} / \mathrm{d}$ ) in multiparous lactating sows fed a low CP diet (14 vs. $20 \%$ ) under heat stress conditions (i.e., $28^{\circ} \mathrm{C}$ ) [14]. In contrast, Quiniou and Noblet did not report any effect of diet on performance of lactating sows kept at $29^{\circ} \mathrm{C}$ when dietary protein content was reduced from 17 to $14 \%$ [15]. According the later authors, the results could be due to the lack of interaction between temperature and diet to the low number of observations and (or) the deficiency in sulphur AA and Trp the low CP diet. The reduction of dietary protein content with a supplementation of industrial AA leads to an increase in the ratio between Trp and branched chain AA (LNAA: Leu, Ile, Val, Phe, Tyr) (i.e., 4.52 vs. 5.37\% in NP and LP diet, respectively). According to Trottier and Easter, the reduction in the Trp:LNAA ratio through dietary addition of LNAA decreased feed intake of primiparous lactating sows [16]. Thus, it could be suggested that the increased ADFI in LP treatment may also be related to a reduced Trp:LNAA ratio. Tryptophan and LNAA share the same neutral carrier system to cross the blood-brain barrier, and they compete for uptake by the brain [17]. Serotonin and its precursor, Tryp, are known to be involved in the control of feed intake; an increased ratio of Tryp:LNAA is reported to increase appetite linearly in growing finishing pigs [18].

Litter BW gain, milk production and composition were not influenced by dietary $\mathrm{CP}$ content. Milk production from farrowing to $\mathrm{d}$ 
27 and litter growth rate for the overall lactation period averaged 7,485 and $2,055 \mathrm{~g} / \mathrm{d}$, respectively. Similarly, Johnston et al. and Renaudeau et al. in lactating sows kept at $29^{\circ} \mathrm{C}$, showed no change in litter BW gain when dietary CP level was decreased (from 16.7 to $13.3 \%$; and from 17.6 to $14.2 \%$, respectively) $[13,19]$. Lactation BW loss was not influenced statistically by treatments $(P>0.10)$, but numerically, the LP sows lost 8 $\mathrm{kg}$ less than the NP sows in agreement with previous results [13]. The LP sows also tended to show a numerically lower backfat loss than NP sows ( 2.4 vs. $6.3 \mathrm{~mm} ; P<0.10$; Table 2). According to several authors theses findings can be attributed to the higher feed intake observed for the LP sows, which probably contributed for the sow to maintain its body condition $[8,13,15]$.

The macro composition of milk is shown in Table 3. According to our findings, dietary protein content did not affect general milk composition and amino acids (AA) milk composition (Table 4). Similar results were reported by Dourmad et al. in primiparous lactating sows when dietary crude protein (CP) level was reduced from 17.1 to $15.5 \%$ without change in lysine concentration $(0.77 \%)$ [7]. For a more severe restriction of dietary $\mathrm{CP}$ ( 15 to $5 \%$ and 23.8 to $6.3 \%$, respectively), Elliott et al. and King et al. showed reduced fat and protein milk contents in low CP treatment [20,21]. In these latter studies, the milk AA composition expressed as a proportion of nitrogen content was slightly affected by protein supply. In particular, they reported a lower proportion of glutamic acid only in milk from sows receiving a diet with less than $10 \%$ dietary CP.

In the present study, milk DM and ash contents linearly increased with the advancement of lactation from 17.6 to $19.9 \%$ and from 0.72 to $0.97 \%$, respectively between $\mathrm{d} 7$ and $\mathrm{d} 27(P<0.01)$. Lactose content

\begin{tabular}{|c|c|c|c|c|c|c|}
\hline \multirow{3}{*}{ No. obs. } & \multicolumn{4}{|c|}{ Lactation day, d } & \multirow{2}{*}{ RSD } & \multirow{2}{*}{ Statistics } \\
\hline & 7 & 14 & 21 & 27 & & \\
\hline & 18 & 18 & 18 & 18 & & \\
\hline \multicolumn{7}{|c|}{ Chemical composition, \% } \\
\hline Dry matter & $17.6^{\mathrm{a}}$ & $19.3^{b}$ & $18.7^{\mathrm{b}}$ & $19.9^{b}$ & 1.2 & $\mathrm{~S}^{\star *}, \mathrm{~B}^{\star *}$ \\
\hline Ash & $0.72^{\mathrm{a}}$ & $0.80^{\mathrm{b}}$ & $0.88^{\mathrm{c}}$ & $0.97^{d}$ & 0.06 & $S^{* *}$ \\
\hline Nitrogen & $0.82^{\mathrm{ab}}$ & $0.80^{\mathrm{a}}$ & $0.83^{\mathrm{ab}}$ & $0.87^{\mathrm{b}}$ & 0.07 & $S^{*}, B^{* *}$ \\
\hline Lipids & 7.12 & 8.00 & 7.07 & 7.65 & 1.06 & \\
\hline Lactose & $3.95^{a}$ & $4.91^{\mathrm{b}}$ & $4.88^{\mathrm{b}}$ & $4.90^{\mathrm{b}}$ & 0.36 & $\mathrm{~S}^{* *}$ \\
\hline
\end{tabular}

${ }^{1}$ Residual Standard Variation; a, b, cWithin a line, means with different superscripts are significantly affected by treatment; ${ }^{2} \mathrm{From}$ an analysis of variance with a general linear model including the effect of diet (D) and batch (B), lactation stage $(S)$ and their interactions as fixed effects. Repeated measurements of milk chemical composition were analysed using an unstructured covariance structure with sows within batch as a subject. Statistical significance: ${ }^{*} P<0.05,{ }^{* *} P<0.01$.

Table 3: Effect of lactation stage on sows milk chemical composition (Least Square Means).

\begin{tabular}{|c|c|c|c|c|c|c|}
\hline & \multicolumn{4}{|c|}{ Lactation day, d } & \multirow{2}{*}{ RSD } & \multirow{2}{*}{ Statistical analysis } \\
\hline & 7 & 14 & 21 & 27 & & \\
\hline No. observations & 18 & 18 & 18 & 18 & & \\
\hline \multicolumn{7}{|c|}{ Essential amino acids, g/16 g N } \\
\hline Lysine & 7.21 & 7.27 & 7.27 & 7.20 & 0.36 & \\
\hline Methionine & 1.80 & 1.81 & 1.83 & 1.82 & 0.07 & \\
\hline Cystine & $1.43^{\mathrm{a}}$ & $1.39^{b}$ & $1.36^{b}$ & $1.29^{c}$ & 0.05 & $\mathrm{~S}^{* \star *}$ \\
\hline Threonine & $4.13^{a}$ & $4.04^{\mathrm{ab}}$ & $4.01^{\mathrm{ab}}$ & $3.98^{\mathrm{b}}$ & 0.15 & $S^{*}$ \\
\hline Tryptophan & $1.34^{a}$ & $1.29^{b}$ & $1.28^{b}$ & $1.28^{\mathrm{b}}$ & 0.06 & $S^{*}$ \\
\hline Valine & $5.24^{a}$ & $5.14^{\mathrm{b}}$ & $5.12^{b}$ & $5.08^{b}$ & 0.12 & $S^{*}$ \\
\hline Leucine & 8.43 & 8.38 & 8.36 & 8.32 & 0.17 & $B^{*}$ \\
\hline Isoleucine & 4.00 & 3.98 & 3.97 & 3.92 & 0.19 & \\
\hline Histidine & 2.58 & 2.59 & 2.58 & 2.57 & 0.10 & \\
\hline Tyrosine & 4.18 & 4.14 & 4.13 & 4.11 & 0.23 & \\
\hline Phenylalanine & 4.02 & 4.01 & 4.02 & 3.96 & 0.11 & \\
\hline Total & 44.4 & 44.0 & 43.9 & 43.5 & 1.4 & \\
\hline \multicolumn{7}{|c|}{ Non essential amino acids, $\mathrm{g} / 16 \mathrm{~g} \mathrm{~N}$} \\
\hline Arginine & 4.64 & 4.59 & 4.58 & 4.65 & 0.11 & $\mathrm{~B}^{*}$ \\
\hline Glycine & $3.08^{a}$ & $3.07^{a}$ & $3.11^{\mathrm{ab}}$ & $3.20^{\mathrm{b}}$ & 0.14 & $S^{*}$ \\
\hline Alanine & $3.63^{a}$ & $3.56^{\mathrm{ab}}$ & $3.54^{\mathrm{ab}}$ & $3.50^{\mathrm{b}}$ & 0.08 & $\mathrm{~S}^{* *}$ \\
\hline Serine & 5.14 & 5.11 & 5.14 & 5.12 & 0.15 & \\
\hline Aspartic acid & 8.05 & 7.95 & 7.97 & 7.96 & 0.19 & \\
\hline Glutamic acid & $19.2^{\mathrm{a}}$ & $19.6^{\mathrm{ab}}$ & $19.8^{b}$ & $19.7^{\mathrm{b}}$ & 0.50 & $S^{*}$ \\
\hline Proline & 10.1 & 10.3 & 10.5 & 10.7 & 0.53 & \\
\hline Total & 53.8 & 54.2 & 54.6 & 54.8 & 1.3 & \\
\hline
\end{tabular}

${ }^{1}$ Residual Standard Variation; ${ }^{a, b, c}$ Within a line, means with different superscripts are significantly affected by treatment; ${ }^{2} \mathrm{From}$ an analysis of variance with a general linear model including the effect of diet (D) and batch (B), lactation stage (S) and their interactions as fixed effects. Repeated measurements of milk chemical composition were analysed using an unstructured covariance structure with sows within batch as a subject. Statistical significance: ${ }^{*} P<0.05$, ${ }^{\star *} P<0.01$.

Table 4: Effect of lactation stage on sows milk protein amino acid composition (Least Square Means). 
increased from $\mathrm{d} 7$ and $\mathrm{d} 14(3.95$ to $4.91 \%, P<0.01)$ and thereafter remained constant. Whatever the stage of lactation, the percentage of fat in milk was constant and averaged $7.46 \%$. Nitrogen milk concentration was significantly affected by stage of lactation being minimum on $\mathrm{d} 14$ and maximum on $\mathrm{d} 27$. Our results for the overall milk composition are essentially the same as those reported by Salmon-Legagneur, Elliott et al., Klobasa et al. and Csapó et al. [20,22-24].

In our study, the AA composition of milk protein generally agreed with those presented by King et al. and Dourmad et al. (Table 4) [7,21]. Milk proteins were particularly rich in glutamic acid, proline, leucine, and aspartic acid (19.6, 10.4, 8.4, and $8.0 \mathrm{~g} / 16 \mathrm{~g} \mathrm{~N}$, respectively). In contrast, tryptophan, cystine, and methionine were present in a least amount in milk (1.3, 1.4 and $1.8 \mathrm{~g} / 16 \mathrm{~g} \mathrm{~N}$, respectively). The AA concentration in milk was affected by the stage of lactation: whereas sulfur AA, threonine, tryptophan, valine, and alanine concentrations decreased $(P<0.05)$ but glycine and glutamic acid contents increased $(P<0.05)$ from $\mathrm{d} 7$ to $\mathrm{d} 27$. Similar results were reported by Csapó et al. and Elliott et al. [21,24]. As the AA are derived from milk proteins, changes in AA patterns during lactation reflect a change in the relative distribution of milk proteins with different AA pattern. According to Klobasa et al. the relative proportion of caseins to whey proteins such as immunoglobulins and $\alpha$-lactalbumin increases during lactation in the sow's milk [23]. In fact, whey proteins in general have a lower concentration of glutamic acid, proline and methionine, and are richer in cysteine, threonine, and valine compared to caseins proteins [5]. From these results, it can be suggested that changes in AA pattern during lactation could be explained by the presence to some extent of immune proteins in mature milk produced after the colostrum stage. On average lysine milk content concentration was not affected by stage of lactation $(P>0.05)$ and averaged $7.24 \mathrm{~g} / 16 \mathrm{~g} \mathrm{~N}$; this value is rather similar to the levels reported by Elliott et al., King et al., and Dourmad et al. (7.30, 6.95, and $7.39 \mathrm{~g}$ lysine / $16 \mathrm{~g} \mathrm{~N}$, respectively) [7,20,21].
The fatty acids composition of milk fat is presented in Table 5. In agreement with data previously published in the literature, more than $80 \%$ of the fatty acids in sow's milk fat were palmitic (16:0), oleic (18:1) and linoleic acids (18:2) (Miller et al., Csapó et al. and Gerfault et al.) [24-26]. According to Darragh and Moughan, most of the fatty acids founds in milk reflect closely those in the blood triacylglycerol which in turn are influenced by the type of dietary fat ingested by the sow and/ or the amount of mobilized maternal fat tissue [5]. In the present study, fatty acids composition in milk fat was not influenced $(P>0.05)$ by the stage of lactation. Similarly, Bee did not report any change in fatty acids concentration in milk sampled on $\mathrm{d} 9,16$ or $\mathrm{d} 23$ [27]. In contrast, Miller et al. and Csapó et al. showed that the proportion of linoleic acids (C18:2) was reduced whereas that of palmitoleic acid (C16:1) increased during lactation $[24,25]$. The discrepancy between the studies can be explained by differences in animal characteristics (genotype, milk production, ability to mobilize body reserves), in animal management (amount and FA composition of the diet; Rosero et al. [28]) or in the method of milk collection [5].

Residual correlations between sow performance and milk composition are presented in Table 6. Logically, the maternal BW loss during lactation was negatively correlated with ADFI $(r=-0.76)$ and positively correlated with backfat thickness loss $(r=0.55)$. In addition, there was a positive correlation between milk production and body reserves mobilisation $(r=0.82)$. This result would suggest that in our experimental conditions in which appetite was limited by the hot environment, the ability of sows to produce milk depends of their capacity to mobilize body reserve for providing milk precursors. The polyunsaturated FA (PUFA) content in milk fat was positively correlated with ADFI and negatively correlated to maternal BW loss $(\mathrm{r}=0.62$ and $\mathrm{r}=-0.60)$. The PUFA deposited in milk fat originated

\begin{tabular}{|c|c|c|c|c|c|c|}
\hline & \multicolumn{4}{|c|}{ Lactation day, d } & \multirow{2}{*}{ RSD } & \multirow{2}{*}{ Statistical analysis } \\
\hline & 7 & 14 & 21 & 27 & & \\
\hline No. observations & 18 & 18 & 18 & 18 & & \\
\hline \multicolumn{7}{|c|}{ Saturated fatty acids, $\mathrm{mg} / \mathrm{L}$} \\
\hline $\mathrm{C} 12: 0$ & 14 & 17 & 17 & 15 & 4 & \\
\hline $\mathrm{C} 14: 0$ & 178 & 195 & 201 & 179 & 36 & \\
\hline C16:0 & 1711 & 1814 & 1869 & 1783 & 295 & \\
\hline C18:0 & 287 & 262 & 258 & 246 & 50 & \\
\hline $\mathrm{C} 20: 0$ & 13 & 16 & 16 & 15 & 7 & \\
\hline Total & 2207 & 2307 & 2364 & 2240 & 362 & \\
\hline Total, \% & 37.1 & 38.0 & 38.9 & 38.0 & 2.6 & \\
\hline \multicolumn{7}{|c|}{ Monounsaturated fatty acids, $\mathrm{mg} / \mathrm{L}$} \\
\hline C14:1 & 11 & 13 & 13 & 12 & 3 & \\
\hline C16:1 & 474 & 483 & 515 & 456 & 99 & \\
\hline C18:1 & 1799 & 1721 & 1751 & 1624 & 426 & \\
\hline C20:1 & 19 & 20 & 21 & 20 & 7 & \\
\hline Total & 2313 & 2245 & 2308 & 2121 & 464 & \\
\hline Total, \% & 38.3 & 36.8 & 37.1 & 35.6 & 4.4 & \\
\hline \multicolumn{7}{|c|}{ Polyunsaturated fatty acids, $\mathrm{mg} / \mathrm{L}$} \\
\hline C18:2 & 1274 & 1335 & 1306 & 1359 & 212 & \\
\hline C18:3 & 92 & 102 & 95 & 103 & 22 & \\
\hline $\mathrm{C} 20: 2$ & 26 & 24 & 27 & 26 & 12 & \\
\hline C20:4 & 37 & 33 & 32 & 32 & 9 & \\
\hline Total & 1410 & 1528 & 1497 & 1567 & 245 & \\
\hline Total, \% & 24.8 & 25.4 & 24.4 & 26.7 & 3.2 & \\
\hline
\end{tabular}

${ }^{1}$ Residual Standard Variation; ${ }^{2}$ From an analysis of variance with a general linear model including the effect of diet (D) and batch (B), lactation stage (S) and their interactions as fixed effects. Repeated measurements of milk chemical composition were analysed using an unstructured covariance structure with sows within batch as a subject. Statistical significance: * $P<0.05,{ }^{* *} P<0.01$.

Table 5: Effect of lactation stage on sows milk fatty acid composition (Least Square Means). 


\begin{tabular}{|c|c|c|c|c|c|}
\hline & ADFI & dlys intake & BW loss & BT loss & Milk \\
\hline ADFI, g/d & 1.00 & - & - & - & - \\
\hline dlys intake, $g / d$ & 0.92 & 1.00 & _- & _ & _ \\
\hline BW loss, g/d & -0.76 & -0.55 & 1.00 & - & - \\
\hline BT loss, g/d & -0.39 & -0.29 & 0.62 & 1.00 & - \\
\hline Milk, g/d & -0.49 & -0.34 & 0.82 & 0.40 & 1.00 \\
\hline Dry matter, \% & 0.14 & 0.10 & 0.05 & 0.37 & 0.09 \\
\hline Ash, \% DM & 0.02 & 0.05 & -0.33 & -0.51 & -0.42 \\
\hline Crude protein, \% DM & -0.17 & 0.01 & 0.08 & -0.43 & 0.19 \\
\hline Fat, \% DM & 0.16 & 0.12 & 0.13 & 0.39 & 0.21 \\
\hline Lactose, \% DM & 0.07 & 0.16 & -0.37 & -0.08 & -0.26 \\
\hline SFA, mg/L & 0.38 & 0.42 & -0.02 & 0.22 & -0.15 \\
\hline MUFA, mg/L & -0.41 & -0.21 & 0.78 & 0.41 & 0.73 \\
\hline PUFA, mg/L & 0.62 & 0.47 & -0.60 & -0.33 & -0.69 \\
\hline Lysine, g/16 g N & -0.39 & -0.53 & -0.04 & -0.31 & -0.20 \\
\hline Sulfur $A A, g / 16 \mathrm{~g} \mathrm{~N}$ & -0.14 & -0.25 & -0.33 & -0.39 & -0.61 \\
\hline Threonine, g/16 g N & -0.16 & -0.33 & -0.31 & -0.40 & -0.49 \\
\hline Tryptophan, g/16 g N & -0.32 & -0.49 & -0.17 & -0.54 & -0.27 \\
\hline Leucine, g/16 g N & 0.58 & 0.41 & -0.74 & -0.09 & -0.79 \\
\hline Isoleucine, $\mathrm{g} / 16 \mathrm{~g} \mathrm{~N}$ & -0.30 & -0.41 & -0.06 & -0.24 & -0.23 \\
\hline Valine, $\mathrm{g} / 16 \mathrm{~g} \mathrm{~N}$ & 0.05 & -0.09 & -0.46 & -0.30 & -0.67 \\
\hline Arginine, $\mathrm{g} / 16 \mathrm{~g} \mathrm{~N}$ & 0.01 & -0.22 & 0.07 & -0.07 & 0.39 \\
\hline Histidine, $\mathrm{g} / 16 \mathrm{~g} \mathrm{~N}$ & -0.65 & -0.31 & -0.12 & -0.21 & -0.26 \\
\hline
\end{tabular}

${ }^{1}$ Sow performance: ADFI (average daily feed intake), Dlys (digestible lysine) intake, BW (body weight) loss, BT (backfat thickness) loss and milk (milk production). SFA MUFA, and PUFA for saturated fatty acids (FA), monounsaturated FA, and polyunsaturated FA, respectively. Correlation coefficient in bold was significantly different from $0(P<0.05)$.

Table 6: Residual correlation coefficients between lactation performance and chemical composition of milk of sows over a 28-d lactation¹.

mainly from dietary FA because animals cannot synthesize them, while saturated FA (SFA) and monounsaturated FA (MUFA) are derived from diet, mobilisation of fat tissue, or de novo synthesis. As a result, when sows are in a negative energy balance, a large amount of body reserves are mobilized and then exogenous PUFA are diluted with endogenous de novo synthesised fatty acids (SFA and MUFA). Finally, except for arginine, negative correlations were reported between milk production and AA concentration; the correlation coefficients were significantly different from zero only for sulphur AA, threonine, branched chain AA (leucine and valine). According to these results, changes in milk production would affect the AA composition of milk proteins. In conclusion, reducing dietary protein content can be an alternative to attenuate the negative effects of heat stress by increasing ADFI. Milk composition changes significantly according to lactation stage and the ability of sows to produce milk will depend on their capacity to mobilize body reserve for providing milk precursors.

\section{Acknowledgements}

The authors gratefully acknowledge Ajinomoto Eurolysine (Paris, France) for their financial support and for measurement of amino acid contents in feeds and in milk; the authors also gratefully acknowledge C. Anäis, M. Bructer, K. Benoni, T. Etienne for their technical assistance.

\section{References}

1. Etienne M, Dourmad JY, Noblet J (1998) The influence of some sow and piglet characteristics and of environmental conditions on milk production. The Lactating Sow, pp: 285-299.

2. Gourdine JL, Renaudeau D, Noblet J, Bidanel JP (2004) Effects of season and parity on performance of lactating sows in a tropical climate. Anim Sci 79 : 273-282.

3. Renaudeau D, Anaïs C, Noblet J (2003) Effects of dietary fiber on performance of multiparous lactating sows in a tropical climate. J Anim Sci 81: 717-725.

4. Silva BAN, Noblet J, Oliveira RFM, Donzele JL, Primot Y, et al. (2009) Effects of dietary protein level and amino acids supplementation on the feeding behavio of multiparous lactating sows in a tropical humid climate. J Anim Sci 87: 2104-2112.
5. Darragh AJ, Moughan PJ (1988) Composition of sow' colostrum and milk In: Verstegen MW, Moughan PJ, Schrama JW (eds.), The Lactating Sow. Wageningen Pers, Wageningen, pp: 1-19

6. Gourdine JL, Bidanel JP, Noblet J, Renaudeau D (2005) Effects of breed and season on performance of lactating sows in a tropical humid climate. J Anim Sci 84: 360-369.

7. Dourmad JY, Noblet J, Etienne M (1998) Effect of protein and lysine supply on performance, nitrogen balance, and body composition changes of sows during lactation. J Anim Sci 76: 542-550.

8. Renaudeau D, Noblet J (2001) Effects of exposure to high ambient temperature and dietary protein level on sow milk production and performance of piglets. $J$ Anim Sci 79: 1540-1548

9. AOAC (1990) Official Methods of Analysis. 15th edn. The Association of Official Analytical Chemists, Washington, DC. P1106.

10. Folch J, Lee M, Sloane Stanley GH (1967) A simple method for the isolation and purification of total lipids from animal tissues. J Biol Chem 226: 497-509.

11. Morrison WR, Smith LM (1964) Preparation of fatty acid methyl esters and dimethylacetals from lipids with boron fluoride methanol. J Lipid Res 5: 600-608.

12. Noblet J, Etienne M (1989) Estimation of sow milk nutrient output. J Anim Sci 67: 3352-3359

13. Renaudeau D, Quiniou N, Noblet J (2001) Effects of exposure to high ambient temperature and dietary protein level on performance of multiparous lactating sows. J Anim Sci 79:1240-1249.

14. Lynch PB (1989) Voluntary food intake of sows and gilts. In: Smith AT Lawrence TLJ (eds.), Pig Housing and the Environment. British Society of Animal Production, Edinburgh, UK, pp: 71-77.

15. Quiniou N, Noblet J (1999) Influence of high ambient temperatures on performance of multiparous lactating sows. J Anim Sci 77: 2124-2134.

16. Trottier NL, Easter RA (1995) Dietary and plasma branched-chain amino acids in relation to tryptophan: Effect on voluntary feed intake and lactation metabolism in the primiparous sow. J Anim Sci 73: 1086-1092.

17. Tackman JM, Tews JK, Harper AE (1990) Dietary disproportions of amino acids in the rats: effects on food intake, plasma and brain amino acids and brain serotonin. J Nutr 120: 521-533. 
Citation: Silva BAN, Gourdine JL, Corrent E, Primot Y, Mourot J, et al. (2017) Effects of Dietary Protein Content on Milk Composition of Mixed Parity Lactating Sows in a Tropical Humid Climate. J Vet Sci Technol 8: 448. doi: 10.4172/2157-7579.1000448

18. Henry Y, Séve B (1993) Feed intake and dietary amino acid balance in growing pigs with special reference to lysine, tryptophan and threonine. Pig News Info 14: 35-43.

19. Johnston LJ, Ellis M, Libal GW, Mayrose VB, Weldon WC, et al. (1999) Effect of room temperature and dietary amino acid concentration on performance of lactating sows. J Anim Sci 77: 1638-1644.

20. Elliott RF, Vander Noot GW, Gilbreath RL, Fisher H (1971) Effect of Dietary Protein Level on Composition Changes in Sow Colostrum and Milk. J Anim Sci 32: $1128-1137$

21. King RH, Toner MS, Dove H, Atwood CS, Brown WG (1993) The response of firstlitter sows to dietary protein level during lactation. J Anim Sci 71: 2457-2463.

22. Salmon-Legagneur $E$ (1965) Some aspects of nutritional relationships between pregnancy and lactation in the sow. Ann Zootech 14: 1-137.

23. Klobasa F, Werhahn E, Butler JE (1987) Composition of sow milk during lactation. J Anim Sci 64: 1458-1466.
24. Csapó J, Martin TG, Csapó-kiss ZS, Hjzas Z (1996) Protein, fats, vitamin and mineral concentrations in porcine colostrum and milk from parturition to 60 days. Int Dairy J 6: 881-902.

25. Miller GM, Conrad JH, Harrington RB (1971) Effect of Dietary Unsaturated Fatty Acids and Stage of Lactation on Milk Composition and Adipose Tissue in Swine. J Anim Sci 32: 79-83.

26. Gerfault V, Mourot J, Etienne M, Mounier A (1999) Influence of the source of lipids added to the sow pregnancy diet on reproductive performance and on body composition of piglets at birth. Journées de la Recherche Porcine en France 31: 191-197.

27. Bee G (2000) Dietary conjugated linoleic acids alter adipose tissue and milk lipids of pregnant and lactating Sows. J Nutr 130: 2292-2298.

28. Rosero DS, Odle J, Mendoza SM, Boyd RD, Fellner V, et al. (2015) Impact of dietary lipids on sow milk composition and balance of essential fatty acids during lactation in prolific sows. J Anim Sci 93: 2935-2947. 